\begin{tabular}{|c|c|c|}
\hline$\underset{P \cup B L I C A T \mid O N}{\operatorname{Na}}$ & $\begin{array}{c}\text { International Journal of Advanced Engineering, Management and Science } \\
\text { (IJAEMS) } \\
\text { Peer-Reviewed Journal } \\
\text { ISSN: 2454-1311 / Vol-7, Issue-6; Jun, } 2021 \\
\text { Journal Home Page: https://ijaems.com/ } \\
\text { Article DOI: https://dx.doi.org/10.22161/ijaems.76.3 }\end{array}$ & (1) \\
\hline
\end{tabular}

\title{
Employee Turnover Intention and Job Satisfaction
}

\author{
Bayad Jamal Ali ${ }^{1}$, Govand Anwar ${ }^{2}$
}

\begin{abstract}
${ }^{1}$ Business Administration Department, Komar University of Science and Technology, Sulaimani 46001, Kurdistan Region - Iraq ${ }^{2}$ Department of Business Administration, College of Administration and Financial Sciences, Knowledge University, 44001 Erbil, Kurdistan Region, Iraq
\end{abstract}

Received: 07 Apr 2021; Received in revised form: 09 May 2021; Accepted: 22 May 2021; Available online: 06 Jun 2021

\begin{abstract}
Today it became a huge challenge for Human Resource Managers to retain the employees for longer time of period and decrease the rate of employee turnover. The main research objective is to find out the correlation between job satisfaction and employee turnover intention in private hospital in Erbil. A quantitative method was used to analyze the current study. 144 participants were involved in this study from private hospital in Erbil. The correlation between job satisfaction factor as independent factor and turnover as dependent factor, the value of $R$ for the Job satisfaction is $=.386^{* *}$ which indicates that turnover is a positive and weak correlation with turnover intention. The coefficients analysis for this study, the value Beta for turnover is $=.386>0.01$, which supported the research hypothesis. This study showed that the there is a positive correlation between job satisfaction and employee turnover. Finally, on the turnover intentions of private hospital personnel in Erbil, most of them would quit in case if they have a better opportunities.
\end{abstract}

Keywords - Job Satisfaction, Private Hospital, Turnover.

\section{INTRODUCTION}

In every organization the Human Resources are considered as the main organizational source (Talim, et al. 2021). Today it became a huge challenge for Human Resource Managers to retain the employees for longer time of period and decrease the rate of employee turnover (Top \& Ali, 2021). Increasing the rate of employee turnover will result in increasing the cost of recruitment accordingly organization's productivity will decrease (Sorguli et al. 2021). At the present time many academicians, human resource managers, researchers and scholars are paying attention on employee turnover (Sabir et al. 2021). Increasing the rate of employee turnover reduces organizational efficiency and productivity (Jamal et al. 2021). Therefore, it is essential to study the relation between employee turnover and job satisfaction (Saleh et al. 2021). (Ismael et al. 2021), defined job satisfaction as emotion or feeling that an employee has regarding current job (Hamza et al. 2021). Also (Hameed \& Anwar, 2018), they pointed out that many academic scholars tried to determine several job satisfaction components, assess relative significance for each job satisfaction components and investigate (Faraj et al. 2021) the influence of all these job satisfaction components on employee's satisfaction and productivity (Demir et al. 2020). Satisfied employees are recognized to demonstrate the higher level of productivity and efficiency in organisations (Aziz et al. 2021). By examining job satisfaction an organisation (Anwar, K., \& Louis, 2017) will be able to increase positive consequences for instance employee satisfaction, and will decrease employee turnover (Anwar, 2017). The main research objective is to find out the correlation between job satisfaction and employee turnover intention in private hospital in Erbil (Anwar, 2016).

\section{LITERATURE REVIEW}

\section{Employee Turnover}

Anwar, (2017), defined employee turnover as a percentage comparison of the number of individuals an organization should replace in a specific time of period to the average amount of total individuals within an organization. (Anwar \& Surarchith, 2015)defined employee turnover as a rotation of individuals around the labor market (Anwar \& Shukur, 2015); it could be between companies, states of 
unemployment and employment, and between occupations and jobs (Anwar \& Qadir, 2017).

A great concern that many organizations, turnover increases cost of the organization particularly in job with minimum wages (Anwar \& Shukur, 2015). There several factors influence the rate of turnover of an organization, and these factors could be from employees and employer (Anwar \& Surarchith, 2015). These factors could be compensation, benefits, wages, and job analysis and so on (Anwar, 2016). According to (Anwar, 2017) in case of turnover, it causes indirect and direct expenses to an organization, which compromises the cost of human resource (Anwar, K., \& Louis, 2017), training, advertising, retention and loss of productivity (Aziz et al. 2021).

According to (Demir et al. 2020) many researchers believed that employee turnover and job satisfaction are negatively associated. Conversely, the opposite view as well exists (Faraj et al. 2021), for instance, the term of employee turnover, a moderately specific perception (Hameed \& Anwar, 2018), can't be fruitfully clarified by more general perceptions for example commitment and job satisfaction (Hamza et al. 2021). The link between employee turnover and job satisfaction could be associated by many factors or variables for instance, compensation, stress, environment, training and so on (Ismael et al. 2021).

A study was carried out in manufacturing industry in Malaysia. The aim of the study was to measure four variables (employee relationship, benefits, compensation (Ismael et al. 2021), working environment and demographic) as independent factor and job satisfaction as dependent factor (Jamal et al. 2021). The outcome of the study proved that managers are required to execute long term plan in order to be able to avoid high employee turnover. Identifying the level of job satisfaction considers an important factor to decrease rate of employee turnover (Sabir et al. 2021).

Anwar, (2017), stated that turnover could be forecasted through using complete measures of level of job satisfaction. Therefore (Saleh et al. 2021), increasing level of job satisfaction is strongly correlated with low rate of turnover (Sorguli et al. 2021). Furthermore, many academic researchers proved that the association between turnover and level of job satisfaction is moderated by turnover intentions (Talim, et al. 2021).

Anwar, (2016), stated that many studies proved a positive relation between individual intention and leaving behavior. Usually, it is considered that employee turnover intention and job satisfaction are inversely associated (Anwar \& Balcioglu, 2016).

The contrast relation between turnover and job satisfaction is very essential (Anwar \& Climis, 2017). One of the major

This article can be downloaded from here: www.ijaems.com objectives of research in turnover is to examine the actual turnover; nonetheless, turnover data is frequently unreachable to scholars (Anwar \& Ghafoor,2017). Regularly, turnover data are not easy to obtain due to it is not precisely or consistently gathered. Therefore (Anwar \& Qadir, 2017), academic scholars should rely on employee turnover intention as an alternative for actual turnover. Therefore, it has been proved that investigative turnover intention considers one of the effective tools (Anwar \& Shukur, 2015), due to the fact is the factor that immediately and always predict turnover (Anwar \& Surarchith, 2015).

Every organization effectively depends on several variables for instance job satisfaction and turnover. In terms of the intention of employee turnover means voluntary an individual leaves its job (Anwar, 2016), which could have negative influence on organization's outcome. Though, follow-up to low levels of job satisfaction, high rate of individual turnover within an organization, therefore, that could be as low compensation, poor training, recruitment and selection, development and so on (Anwar, 2017).

Employee turnover will have a negative influence on an organization, especially in terms of expenses, so, turnover causes huge cost to an organization (Anwar, K., \& Louis, 2017). In case of turnover, organization should set up a new replacement, time management, training, selection, and recruitment) all these variables will cause a huge cost to an organization (Aziz et al. 2021).

However, different individuals have different methods of turnover. For instance, an individual with a pleased disposition mostly is less likely would leave her or his position (Demir et al. 2020). In some cases, an organization might know the variables that might lead the individual to leave her or his job (Faraj et al. 2021), may be could help an organization to decrease the rate by conduction several method of solving for instance could confirm that individuals are in a high level of job satisfaction (Hameed \& Anwar, 2018). Furthermore, individual with high level of turnover intention more often consider as less effective and always attempt to find a way to leave the organization (Hamza et al. 2021). As many scholars proved the main reason of increasing rate of individual turnover in the workplace is level of job satisfaction. Mainly dissatisfied individuals are willing to leave the organization (Ismael et al. 2021).

\section{Job Satisfaction}

According to (Ali, 2021) job satisfaction is defined as an attitude related with an individuals' degree of their dislike or like their current job. (Ali, et al. 2021) defined job satisfaction as a consequence of various elements such as satisfaction, promotion, relationships among employees, 
pay and equal employment opportunity (Anwar \& Abd Zebari, 2015). (Anwar \& Abdullah, 2021)defined job satisfaction as the positive emotional feeling consequence from achieving what an individual desires or values from his or her current job (Anwar \& Balcioglu, 2016).

(Anwar \& Climis, 2017)defined job satisfaction as a positive feeling consequence from the assessment of an individuals“ job. (Anwar \& Ghafoor,2017)defined job satisfaction as person's overall attitude toward job. (Anwar \& Qadir, 2017) stated that inspiration is closely associated to job satisfaction (Anwar \& Shukur, 2015). Many factors are related to job satisfaction for instance, social relationships, job analysis (Anwar \& Surarchith, 2015), employee training, desires and needs, recruitment and selection, orientation, working conditions, development and quality of management (Anwar, 2017).

Conceptual framework

Research Model

H1

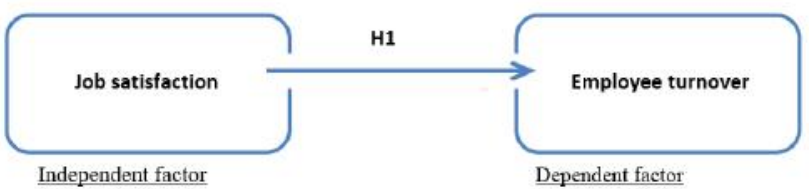

Research Hypotheses:
H1: There is a positive correlation between job satisfaction and employee turnover.

\section{RESEARCH METHODOLOGY}

\section{Design of the Study}

The purpose of this research is to investigate the impact of job satisfaction on employee turnover in private hospital in Erbil. The questionnaire was divided into two sections, the first section consisted of demographic questions; starting with respondent's age and respondents' gender. The second part of questionnaire consisted of 39 questions, 18 questions for employee turnover and 11 questions for job satisfaction.

\section{Sampling Size and Target Population}

A random sampling technique was used, where all employees had equal chances of being selected for the sample. The study was carried out at private hospital in Erbil. The researchers distributed 170 questionnaires, only 156 questionnaires were received and from 156 questionnaires only 144 questionnaires were completed properly.

\section{Instruments}

The questionnaire is structured in the form of multiple choice questions. The participants were asked to rate how strongly they agree on each item on a five points Likert order scale. The questionnaire is designed and adapted from Atteya, 2013; Olusegun, 2013.

\section{RESULTS AND ANALYSIS}

Table 1-Demographic analysis

\begin{tabular}{|c|c|c|c|}
\hline Items & Scales & Frequency & Percent \\
\hline \multirow{4}{*}{ Age } & $\mathbf{2 0 - 2 5}$ & 41 & 28.5 \\
\cline { 2 - 4 } & $\mathbf{2 6 - 3 0}$ & 30 & 20.8 \\
\cline { 2 - 4 } & $\mathbf{3 1 - 3 5}$ & 26 & 18.1 \\
\cline { 2 - 4 } & $\mathbf{3 6 - 4 0}$ & 20 & 13.9 \\
\cline { 2 - 4 } & $\mathbf{4 0 - 4 5}$ & 16 & 7.1 \\
\cline { 2 - 4 } & $\mathbf{4 5}$ and above & 11 & 64.6 \\
\hline \multirow{5}{*}{ Gender } & Male & 93 & 35.4 \\
\cline { 2 - 4 } & Female & 51 & \\
\hline
\end{tabular}

Table (1), shows demographic analysis for respondents participated in this study. 41 participants were from age 2025 years old, 30 respondents were from age 26-30 years old, 26 respondents were from age 31-35 years old, 20 respondents were from age 36-40 years old, 16 respondents were from age 40-45 years old and only 11 respondents were from age 45 years old and above. In terms of participants' gender; 93 participants were male and 51 participants were female.

This article can be downloaded from here: $\underline{w w w . i j a e m s . c o m}$ 
Table 2- Factor analysis

\begin{tabular}{|c|c|c|}
\hline Factor & Items & Factor loading \\
\hline \multirow{8}{*}{ Turnover } & $\begin{array}{l}\text { I would quit my present job for a similar position with better pay in another } \\
\text { organization at the least opportunity }\end{array}$ & .512 \\
\hline & Continuation with my present employer will not fulfill my life expectation & .613 \\
\hline & As soon as I can find a better job, I will quit this organization & .704 \\
\hline & I often think about quitting my job & .811 \\
\hline & $\begin{array}{l}\text { I will probably look for a job outside of this organization within the next } 3 \\
\text { years }\end{array}$ & .757 \\
\hline & It is very unlikely that I would ever consider leaving this organization & .614 \\
\hline & I prefer very much not to continue working for this organization & .534 \\
\hline & I will likely actively look for a new job in the next year. & .789 \\
\hline \multirow{6}{*}{$\begin{array}{l}\text { Job } \\
\text { satisfaction }\end{array}$} & I consider my job unpleasant. & .656 \\
\hline & I am often bored with my job. & .898 \\
\hline & I feel fairly well satisfied with my present job. & .749 \\
\hline & Most of the time, I have to force myself to go to work. & .715 \\
\hline & Most days, I am enthusiastic about my work. & .864 \\
\hline & I am disappointed I ever took this & .766 \\
\hline
\end{tabular}

Factor analysis determines essential variables that clarify the outline of associations within a set of perceived variables. Factor analysis is frequently used in reducing data to classify a small number of variables that clarify most of the variance perceived in greater number of visible variables. Table (2) indicates that the turnover factor has 8 items and job satisfaction factor has 6 items. 
Table 3-Reliability Statistics

\begin{tabular}{|c|c|c|}
\hline \multicolumn{2}{|c|}{} \\
\hline Factor & Cronbach's Alpha & N of Items \\
\hline Turnover & .812 & 6 \\
\hline Job satisfaction & .799 & 13 \\
\hline Turnover and job satisfaction & .805 & 7 \\
\hline
\end{tabular}

Table (3) shows the reliability analysis for both factors (turnover and job satisfaction). According to the reliability tests, the researchers found out Cronbach's Alpha for turnover items $=.812$ which are greater than .6 this means that 7 items for turnover factor were reliable for this study and the Cronbach's Alpha for job satisfaction items $=.799$ which are greater than .6 this means that 6 items for job satisfaction factor were reliable for this study and the out Cronbach's Alpha for turnover and job satisfaction items $=.805$ which are greater than .6 this means that 13 items for turnover and job satisfaction factors were reliable for this study.

Table 4-Correlations analysis

\begin{tabular}{l|l|c|c}
\hline \multirow{4}{*}{ turnover } & turnover & Job satisfaction \\
\hline \multirow{4}{*}{ satisfaction } & Pearson Correlation & 1 & $.386^{* *}$ \\
\cline { 2 - 4 } & Sig. (2-tailed) & & .000 \\
\cline { 2 - 4 } & $\mathrm{N}$ & 144 & 144 \\
\cline { 2 - 4 } & Searson Correlation & $.386^{* *}$ & 1 \\
\cline { 2 - 4 } & Sig. (2-tailed) & .000 & 144 \\
\cline { 2 - 4 } & $\mathrm{N}$ & 144 & \\
\hline
\end{tabular}

**. Correlation is significant at the 0.01 level (2-tailed).

Table (4) shows the correlation between job satisfaction factor as independent factor and turnover as dependent factor. The value of $\mathrm{R}$ for the Job satisfaction $=.386^{* *}$ which indicates that turnover is significantly but has weak correlation with turnover intention.

Table 5-Model Summary

\begin{tabular}{|c|c|c|c|c|}
\hline Model & $\mathbb{R}$ & R Square & Adjusted R Square & $\begin{array}{c}\text { Std. Error of the } \\
\text { Estimate }\end{array}$ \\
\hline 1 & $386^{\mathrm{a}}$ & .149 & .143 & 1.57898 \\
\hline
\end{tabular}

As seen in the table (5), the value of $\mathrm{R}$ square $=.149$ which indicates that $15 \%$ of variables have been explained.

Table 6-ANOVA

\begin{tabular}{l|l|r|r|r|r|l}
\hline \multicolumn{2}{l|}{ Model } & Sum of Squares & df & Mean Square & F & Sig. \\
\hline \multirow{3}{*}{1} & Regression & 61.967 & 1 & 61.967 & 24.855 & $.000^{\mathrm{b}}$ \\
\cline { 2 - 7 } & Residual & 354.033 & 142 & 2.493 & & \\
\cline { 2 - 7 } & Total & 416.000 & 143 & & & \\
\hline
\end{tabular}

a. Dependent Variable: Turnover

This article can be downloaded from here: $\underline{w w w . i j a e m s . c o m}$ 
b. Predictors: (Constant), Job satisfaction

Table (6) shows the value of $\mathrm{F}$ for an independent factors and a dependent factor is $24.855>1$ which indicates there is a significant association between three independent factors and dependent factor.

Table 7-Coefficientsa

\begin{tabular}{|c|c|c|c|c|c|c|}
\hline \multirow[t]{2}{*}{$\overline{\text { Model }}$} & & \multicolumn{2}{|c|}{ Unstandardized Coefficients } & \multirow{2}{*}{$\begin{array}{c}\begin{array}{l}\text { Standardized } \\
\text { Coefficients }\end{array} \\
\text { Beta }\end{array}$} & $t$ & \multirow[t]{2}{*}{ Sig. } \\
\hline & & $\bar{B}$ & Std. Error & & & \\
\hline \multirow{2}{*}{1} & (Constant) & 5.942 & 2.022 & & 2.939 & .004 \\
\hline & turnover & 2.512 & .504 & .386 & 4.985 & .000 \\
\hline
\end{tabular}

a. Dependent Variable: Turnover

Table (7) shows the coefficients analysis for this study. As seen in the above table the value Beta for turnover $=.386>$ 0.01 , this indicates that turnover factor was positively and weak correlation with job satisfaction.

\section{CONCLUSION}

According to the research findings, the following conclusions are illustrated. Job satisfaction has significant but weak influence (.386) on turnover intention of the participants. The outcome of this research could be used as useful administrative tools that might further improve the hospitals'effectiveness and efficiency. On job satisfaction, most of participants are unclear regarding the level of job satisfaction in their hospital. This demonstrates that there is still need for enhancement in their service. This study showed that the greater is the employee's Job satisfaction the less likely they are to express the intention to quit. Finally, on the turnover intentions of private hospital personnel in Erbil, most of them would quit in case if they have a better opportunities.

\section{REFERENCES}

[1] Top, C., \& Ali, B. J. (2021). Customer satisfaction in online meeting platforms: Impact of efficiency, fulfillment, system availability, and privacy. Amazonia Investiga, 10(38), 7081. https://doi.org/10.34069/AI/2021.38.02.7

[2] Demir, A., Maroof, L., Sabbah Khan, N.U. and Ali, B.J. (2020), "The role of E-service quality in shaping online meeting platforms: a case study from higher education sector", Journal of Applied Research in Higher Education. https://doi.org/10.1108/JARHE-08-2020-0253

[3] Ali, B, J. (2021). Impact of consumer animosity, boycott participation, boycott motivation, and product judgment on purchase readiness or aversion of Kurdish consumers in Iraq. Journal of Consumers Affaires; 1-20. https://doi.org/10.1111/joca.12350
[4] Ali, B, J. (2020). Impact of COVID-19 on consumer buying behavior toward online shopping in Iraq. Economic studies journal. 18(42): 267-280. Retrieved from https://www.asjp.cerist.dz/en/article/134070

[5] Ali, B.J. (2021) Assessing (The impact) of advertisement on customer decision making: Evidence from an educational institution. Afak for sciences journal, 6(1): 425-439. Retrieved from https://www.asjp.cerist.dz/en/article/141056

[6] Ali, B.J. (2021) Consumer attitudes towards healthy and organic food in the Kurdistan region of Iraq. Management Science Letters. 11: 1-8. DOI: 10.5267/j.msl.2021.2.015

[7] Andavar, V., Ali, B.J., and Ali, S.A. (2020) Rainwater for Water Scarcity Management: An Experience of Woldia University (Ethiopia). Journal of Business, Economics and Environmental Studies, 10-(4): 29-34. DOI: 10.13106/jbees.2020.vol10.no4.29

[8] Faraj, K. M., Faeq, D. K., Abdulla, D. F., Ali, B. J., \& Sadq, Z. M. (2021). Total Quality Management And Hotel Employee Creative Performance: The Mediation Role Of Job Embeddedment. Journal of Contemporary Issues in Business and Government, 27(1), 3838-3855. http://dx.doi.org/10.47750/cibg.2021.27.01.001

[9] Ali, B. J. (2016). Iraq Stock Market and its Role in the Economy. Retrieved from https://www.amazon.com/IraqStock-Market-Role-Economy/dp/3659634271

[10] Ali, B. J. (2014). Brand Building in the Consumer Electronics Industry in Iraq. Retrieved from https://www.amazon.com/Brand-Building-ConsumerElectronics-Industry/dp/6200248699

[11] Ali, B. J., \& Anwar, G. (2021). Factors Influencing the Citizens' Acceptance of Electronic Government. International Journal of Engineering, Business and Management, $\quad 5(1), \quad 48-60$. https://doi.org/10.22161/ijebm.5.1.5

[12] Saleh, P. F., Ali, B. J., Akoi, S., Najmalddin, B., Ali, R. S., \& Anwar, G. (2021). Factors affecting the Success of Female Entrepreneurs in Kurdistan. International journal of Engineering, Business and Management (IJEBM), 5.

[13] Ali, B. J., \& Anwar, G. (2021). The Effect of Marketing Culture Aspects of Healthcare Care on Marketing

This article can be downloaded from here: $\underline{w w w . i j a e m s . c o m}$ 
Creativity. International Journal of English Literature and Social Sciences, 6(2), 171-182. https://doi.org/10.22161/ijels.62.25

[14] Ali, B. J., \& Anwar, G. (2021). An Empirical Study of Employees' Motivation and its Influence Job Satisfaction. International Journal of Engineering, Business and Management, $\quad 5(2), \quad 21-30$. https://doi.org/10.22161/ijebm.5.2.3

[15] Ali, B. J., Saleh, P. F., Akoi, S., Abdulrahman, A. A., Muhamed, A. S., Noori, H. N., \& Anwar, G. (2021, May). Impact of Service Quality on the Customer Satisfaction: Case study at Online Meeting Platforms. In Ali, BJ, Saleh, Akoi, S., Abdulrahman, AA, Muhamed, AS, Noori, HN, Anwar, G.(2021). Impact of Service Quality on the Customer Satisfaction: Case study at Online Meeting Platforms. International journal of Engineering, Business and Management (Vol. 5, No. 2, pp. 65-77).

[16] Ali, B. J., \& Anwar, G. (2021). The balanced scorecard's evolution as a strategic mechanism at banking sectors. International Journal of English Literature and Social Sciences, 6(1), 471-478. https://doi.org/10.22161/ijels.61.63

[17] Anwar, G., \& Abdullah, N. N. (2021). Inspiring future entrepreneurs: The effect of experiential learning on the entrepreneurial intention at higher education. International Journal of English Literature and Social Sciences, 6.

[18] Ali, B. J., \& Anwar, G. (2021). Measuring competitive intelligence Network and its role on Business Performance. International Journal of English Literature and Social Sciences, 6(2), 329-345. https://dx.doi.org/10.22161/ijels.62.50

[19] Anwar, G., \& Abdullah, N. N. (2021). The impact of Human resource management practice on Organizational performance. International journal of Engineering, Business and Management (IJEBM), 5.

[20] Abdullah, N. N., \& Anwar, G. (2021). An Empirical Analysis of Natural Gas as an Alternative Fuel for Internal Transportation. International Journal of English Literature and Social Sciences, 6(1).

[21] Ali, B. J., \& Anwar, G. (2021). A study of knowledge management alignment with production management: A study of carpet manufacture in Kurdistan region of Iraq. International Journal of English Literature and Social Sciences, 6(2), 346-360. https://dx.doi.org/10.22161/ijels.62.51

[22] Ali, B. J., \& Anwar, G. (2021). The mediation role of change management in employee development. International Journal of English Literature and Social Sciences, 6(2), 361-374. https://dx.doi.org/10.22161/ijels.62.52

[23] Anwar, K., \& Louis, R. (2017). Factors Affecting Students' Anxiety in Language Learning: A Study of Private Universities in Erbil, Kurdistan. International Journal of Social Sciences \& Educational Studies, 4(3), 160.

[24] Ali, B. J., \& Anwar, G. (2021). Business strategy: The influence of Strategic Competitiveness on competitive advantage. International Journal of Electrical, Electronics and Computers, 6(2), 1-10.

https://dx.doi.org/10.22161/eec.62.1

[25] Anwar, K. (2017). Leading Construction Project Teams: The Effectiveness of Transformational Leadership in Dynamic Work Environments in Kurdistan. International Journal of Advanced Engineering, Management and Science, 3(10), 239925.

[26] Ali, B. J., \& Anwar, G. (2021). Strategic leadership effectiveness and its influence on organizational effectiveness. International Journal of Electrical, Electronics and Computers, 6(2), 11-24. https://dx.doi.org/10.22161/eec.62.2

[27] Anwar, K., \& Qadir, G. H. (2017). A Study of the Relationship between Work Engagement and Job Satisfaction in Private Companies in Kurdistan. International Journal of Advanced Engineering, Management and Science, 3(12), 239944.

[28] Ali, B. J., \& Anwar, G. (2021). Intellectual capital: A modern model to measure the value creation in a business. International journal of Engineering, Business and Management, 5(2), 31-43. https://dx.doi.org/10.22161/ijebm.5.2.4

[29] Ali, B. J., \& Anwar, G. (2021). Marketing Strategy: Pricing strategies and its influence on consumer purchasing decision. International journal of Rural Development, Environment and Health Research, 5(2), 26-39. https://dx.doi.org/10.22161/ijreh.5.2.4

[30] Anwar, K. (2017). Factors Affecting Stock Exchange Investment In Kurdistan. The International Journal of Accounting and Business Society, 25(1), 32-37.

[31] Ali, B. J., \& Anwar, G. (2021). Organization citizenship behaviour as a determining Factor in Business outcome. International journal of Rural Development, Environment and Health Research, 5(2), 17-25. https://dx.doi.org/10.22161/ijreh.5.2.3

[32] Anwar, K., \& Climis, R. (2017). Analyzing the relationship between types of advertisement and customer choice: a study of retailer stores in erbil. The International Journal of Accounting and Business Society, 25(2), 43-52.

[33] Talim, S.R., Ali, B.J., Top, C. (2021). Elaborating the Antecedents of Purchase Intentions in Second-Hand Car Industry: Case Study in Kurdistan Region of Iraq. Journal of Contemporary Issues in Business and Government, 27(3), 1526-1547. http://dx.doi.org/10.47750/cibg.2021.27.03.204

[34] Anwar, K., \& Ghafoor, C. (2017). Knowledge management and organizational performance: A study of private universities in Kurdistan. International Journal of Social Sciences \& Educational Studies, 4(2), 53.

[35] Ali, B. J., Saleh, Akoi, S., Abdulrahman, A. A., Muhamed, A. S., Noori, H. N., Anwar, G. (2021). Impact of Service Quality on the Customer Satisfaction: Case study at Online Meeting Platforms. International journal of Engineering, Business and Management, 5(2), 65-77. https://dx.doi.org/10.22161/ijebm.5.2.6

[36] Hameed, A. A., \& Anwar, K. (2018). Analyzing the Relationship between Intellectual Capital and Organizational Performance: A Study of Selected Private 
Banks in Kurdistan. International Journal of Social Sciences \& Educational Studies, 4(4), 39.

[37] Jamal Ali, B., Akoi, S., Fadel Saleh, P., \& Sardar, zhilwan. (2021). Factors Shaping Customer Satisfaction with Residential Flats: Evidence from Sulaymaniyah City. Black Sea Journal of Management and Marketing, 2(2), 1-12. https://doi.org/10.47299/bsjmm.v2i2.69

[38] Akoi, S., Jamal Ali, B., Fadel Saleh, P., Najmalddin, B., Sabah Mustafa, R., Rzgar Abdulmajid, M., \& Rebwar Hama, A. (2021). Elaborating the Characteristics that Affect Buyers in Online Shopping: The Case of Generation Z Girls in Kurdistan Region of Iraq. Black Sea Journal of Management and Marketing, 2(2), 42 - 64. https://doi.org/10.47299/bsjmm.v2i2.74

[39] Anwar, K. (2017). The Role of Effective Leadership in Crisis Management: Study of Private Companies in Kurdistan. Qalaai Zanist Scientific Journal, 2(4), 326-338.

[40] Ahmed, S. Y., Ali, B. J., Top, C. (2021). Understanding the Impact of Trust, Perceived Risk, and Perceived Technology on the Online Shopping Intentions: Case Study in Kurdistan Region of Iraq. Journal of Contemporary Issues in Business and Government, 27(3), 2136-2153. http://dx.doi.org/10.47750/cibg.2021.27.03.264

[41] Anwar, K., \& Balcioglu, H. (2016). The relationship between transformational leadership characteristics and effectiveness: A case study of construction companies in Erbil. International Journal of Science Technology and Management, 5(2), 250-256.

[42] Sabir, B. Y., Othman, B .J., Gardi, B., Ismael, N. B., Hamza, P. A., Sorguli, S., Aziz, H. M., Ahmed, S. A., Ali, B. J., Anwar, G. (2021). Administrative Decentralization: The Transfer of Competency from The Ministry of Education to General Directorates. International Journal of Rural Development, Environment and Health Research, 5(3), 113. https://doi.org/10.22161/ijreh.5.3.1

[43] Abdullah, M. S., Toycan, M., \& Anwar, K. (2017). The cost readiness of implementing e-learning. CUSTOS E AGRONEGOCIO ON LINE, 13(2), 156-175.

[44] Ali, B. J., Anwar, G., Gardi, B., Othman, B. J., Aziz, H. M., Ahmed, S. A., Hamza, P. A., Ismael, N. B., Sorguli, S., Sabir, B. Y. (2021). Business Communication Strategies: Analysis of Internal Communication Processes. Journal of Humanities and Education Development, 3(3), 16-38. https://doi.org/10.22161/jhed.3.3.4

[45] Anwar, K. (2016). Comparison between cost leadership and differentiation strategy in agricultural businesses. Custos $E$ Agronegocio on Line, 12(2), 212-231.

[46] Ali, B. J., Gardi, B., Othman, B. J., Ismael, N. B., Sorguli, S., Sabir, B. Y., Ahmed, S. A., Hamza, P. A., Aziz, H. M., Anwar, G. (2021). Educational system: The policy of Educational system in Kurdistan Region in public Kindergarten. International Journal of English Literature and Social Sciences, 6(3), 062-071. https://doi.org/10.22161/ijels.63.10

[47] Anwar, K. (2017). Analyzing the conceptual model of service quality and its relationship with guests'satisfaction: a study of hotels in erbil. The International Journal of Accounting and Business Society, 25(2), 1-16.
[48] Aziz, H. M., Othman, B. J., Gardi, B., Ahmed, S. A., Sabir, B. Y., Ismael, N. B., Hamza, P. A., Sorguli, S., Ali, B. J., Anwar, G. (2021). Employee Commitment: The Relationship between Employee Commitment And Job Satisfaction. Journal of Humanities and Education Development, 3(3), 54-66. https://doi.org/10.22161/jhed.3.3.6

[49] Anwar, G., \& Shukur, I. (2015). The Impact of Service Quality Dimensions on Students' Satisfaction. International Journal of Social Sciences \& Educational Studies, 76.

[50] Ali, B. J., Gardi, B., Othman, B. J., Ahmed, S. A., Ismael, N. B., Hamza, P. A., Aziz, H. M., Sabir, B. Y., Anwar, G. (2021). Hotel Service Quality: The Impact of Service Quality on Customer Satisfaction in Hospitality. International Journal of Engineering, Business and Management, 5(3), 14-28. https://doi.org/10.22161/ijebm.5.3.2

[51] Anwar, G., \& Surarchith, N. K. (2015). Factors Affecting Shoppers' Behavior in Erbil, Kurdistan-Iraq. International Journal of Social Sciences \& Educational Studies, 1(4), 10.

[52] Sorguli, S., Gardi, B., Othman, B.J., Aziz, H. M., Ahmed, S. A., Sabir, B. Y., Ismael, N. B., Hamza, P. A., Ali, B. J., Anwar, G. (2021) Innovation: Knowledge Management in the Innovating Industries, 6(3), 10-23. https://dx.doi.org/10.22161/eec.63.2

[53] Anwar, G., \& Abd Zebari, B. (2015). The Relationship between Employee Engagement and Corporate Social Responsibility: A Case Study of Car Dealership in Erbil, Kurdistan. International Journal of Social Sciences \& Educational Studies, 2(2), 45.

[54] Hamza, P. A., Othman, B. J., Gardi, B., Sorguli, S., Aziz, H. M., Ahmed, S. A., Sabir, B. Y., Ismael, N. B., Ali, B. J., Anwar, G. (2021). Recruitment and Selection: The Relationship between Recruitment and Selection with Organizational Performance. International Journal of Engineering, Business and Management, 5(3), 1-13. https://doi.org/10.22161/ijebm.5.3.1

[55] Anwar, G., \& Shukur, I. (2015). the impact of recruitment and selection on job satisfaction: Evidence from private school in Erbil. International Journal of Social Sciences \& Educational Studies, 1(3), 4-13.

[56] Ali, B. J., Gardi, B., Othman, B. J., Sabir, B. Y., Sorguli, S., Ismael, N. B., Hamza, P.A., Aziz, H. M., Ahmed, A. A., Anwar, G. (2021). The Role of Shopping Malls on Kurdistan Regional Government's Economy. Journal of Humanities and Education Development, 3(3), 39-53. https://doi.org/10.22161/jhed.3.3.5

[57] Anwar, G., \& Shukur, I. (2015). Job satisfaction and employee turnover intention: A case study of private hospital in Erbil. International Journal of Social Sciences \& Educational Studies, 2(1), 73.

[58] Ahmed, S. A., Othman, B. J., Gardi, B., Sabir, B. Y., Ismael, N. B., Hamza, P. A., Sorguli, S., Aziz, H. M., Ali, B. J., Anwar, G. (2021). Students' Attitudes towards Learning English in the Kurdistan region of Iraq. International Journal of English Literature and Social Sciences, 6(3), 072-087. https://doi.org/10.22161/ijels.63.11 
[59] Anwar, G., \& Shukur, I. (2015). The Impact of Training and Development on Job Satisfaction: A Case Study of Private Banks in Erbil. International Journal of Social Sciences \& Educational Studies, 2(1), 65.

[60] Ismael, N. B., Othman, B. J., Gardi, B., Hamza, P. A., Sorguli, S., Aziz, H. M., Ahmed, S. A., Sabir, B. Y., Ali, B. J., Anwar, G. (2021). The Role of Training and Development on Organizational effectiveness. International Journal of Engineering, Business and Management, 5(3), 15-24. https://doi.org/10.22161/ijebm.5.3.3 